\title{
COMPARATIVE STUDY OF TIG WELDING AND MIG WELDING BY VARYING PARAMETERS
}

\section{MOHAMMED ASIF KATTIMANI, PRASHANTH \& D. H. PACHCHINAVAR}

Assistant Professors Department of Mechanical Engineering, Lords Institute of Engineering and Technology,

Hyderabad-India

\section{ABSTRACT}

In this research, studies were done on the material characterization of stainless steel weld produced by Tungsten inert gas welding (TIG) and metal inert gas welding (MIG). The effects of various process parameters on weld ability of stainless steel were studied. In this process major process parameters like current, type of joint and weld time required for welding is varied and their effect on impact strength and hardness was examined by mechanical testing and non destructive testing (NDT).Through the comparison of both after the testing the significance of the process abnormalities and the recommendations for better weld quality were also presented.

KEYWORDS: TIG Welding, MIG Welding, Hardness, Mechanical Testing, NDT

Received: Jun 09, 2020; Accepted: Jun 29, 2020; Published: Aug 14, 2020; Paper Id.: IJMPERDJUN2020774

\section{INTRODUCTION:}

\subsection{Metal Inert Gass Welding (MIG)}

In this type of welding process a continuous and consumable wire electrode is used. A shielding gas generally argon or sometimes mixture of argon and carbon dioxide are blown through a welding gun to the weld zone [1].Figure 1 represent the MIG weld components.

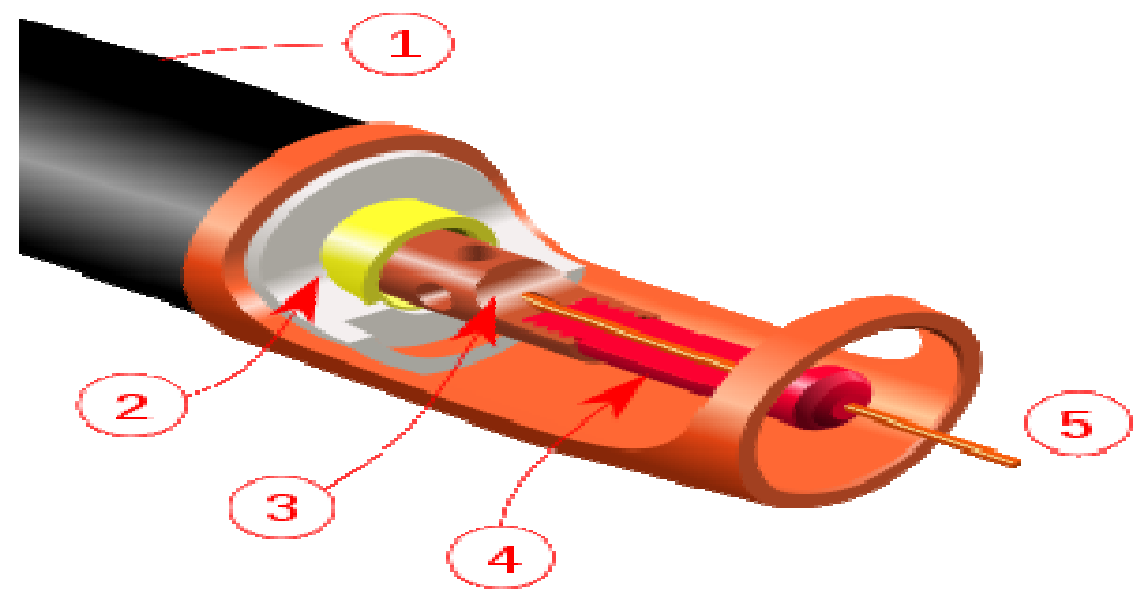

Figure 1: MIG Torch Nozzle Cutaway Image, (1) Torch Handle, (2) Molded Phenolic Dielectric (Shown In White) and Threaded Metal Nut Insert (Yellow), (3) Shielding Gas Diffuser, (4) Contact Tip, (5) Nozzle Output Face.

\subsection{Tungsten Inert Gas Welding (TIG)}

Tungsten Inert Gas welding process is an arc welding process uses a non consumable tungsten electrode to produce 
the weld. The weld area is protected from atmosphere with a shielding gas generally Argon or Helium or sometimes mixture of Argon and Helium. Many industries use TIG for welding thin work pieces, especially nonferrous metals [2]. The use of TIG today has spread to a variety of metals like stainless steel, mild steel and high tensile steels, Al alloy, Titanium alloy.

TIG welding process is most suitable for metal plate of thickness of about $5-7 \mathrm{~mm}$ [3].Figure 2 represent the TIG welding operations.

Figure 2 shows in Tungsten inert gas welding (TIG) and metal inert gas welding (MIG) processes, the common parameters that influence a good quality and productivity are the arc voltage, welding speed and arc current [4-6].

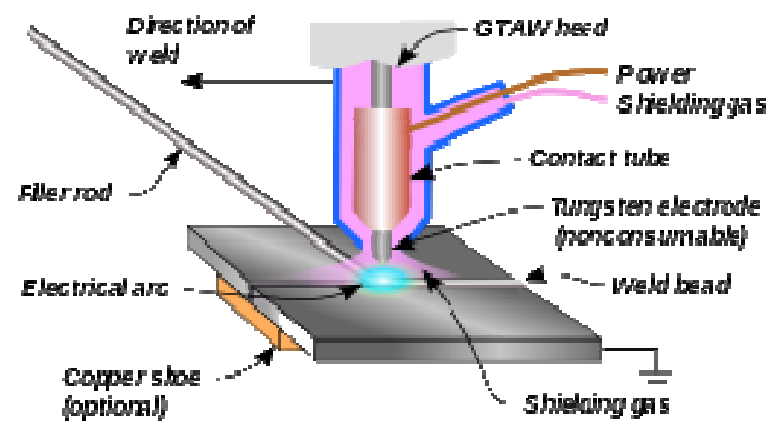

Figure 2: TIG Weld Area.

\section{MATERIAL \& EXPERIMENTAL PROCEDURE}

A wide variety of categorizing joining processes. Welding process wherein coalesce is produced by touching the tip of a coated electrode to the work piece and then with- drawing it quickly to a distance sufficiently to maintain the arc. Tensile strength, Effect of current, electrode diameter, number of passes, and voltage and electrode has enormous effect on mechanical properties of weld, HAZ, weld bead shape and size.

The material used in the experiment is flat plate of length 3 meters and width $0.05 \mathrm{~m}$. The chemical composition of stainless steel is shown in table 1 below.

Table 1: Composition of SS (304)

\begin{tabular}{|c|c|}
\hline Composition of SS (304) & \% \\
\hline Carbon & $0.08 \mathrm{max}$ \\
\hline Manganese & $2.00 \mathrm{max}$ \\
\hline Phosphorus & $0.045 \mathrm{max}$ \\
\hline Sulfur & $0.030 \mathrm{max}$ \\
\hline Silicon & $0.75 \mathrm{max}$ \\
\hline Chromium & $18.00-20.00$ \\
\hline Nickel & $8.00-12.00$ \\
\hline Nitrogen & $0.10 \mathrm{max}$ \\
\hline Iron & Balanced \\
\hline
\end{tabular}

\subsection{Experimental Procedure}

- Take the Stainless Steel of dimension $3 \mathrm{~m} * 0.5 \mathrm{~m} * 0.003 \mathrm{~m}$.

- The Material is cut into 18 pieces each of dimensions $150 \mathrm{~mm} * 50 \mathrm{~mm} * 3 \mathrm{~mm}$.

- Bevel angle of 45 degree is made on 9 pieces and other 9 pieces is square in shape. 
- According to required parameter the work pieces are arranged and the types of joints are square-square (S.S Joint), $\mathrm{V}-\mathrm{V}$ joint, Square $\mathrm{S}-\mathrm{V}$ joint.

- The parameters which are going to be varied are voltage, current, type of joint, welding speed and heat input.

- For first three experiments the parameter of voltage is kept at 70 volts and current is kept at $350 \mathrm{amp}$, welding is done and weld time is noted as shown in figure 3.

- The experiment is again repeated by varying the current at 80 and 90 amps.

- The same procedure is repeated for MIG welding as shown in Figure 4.

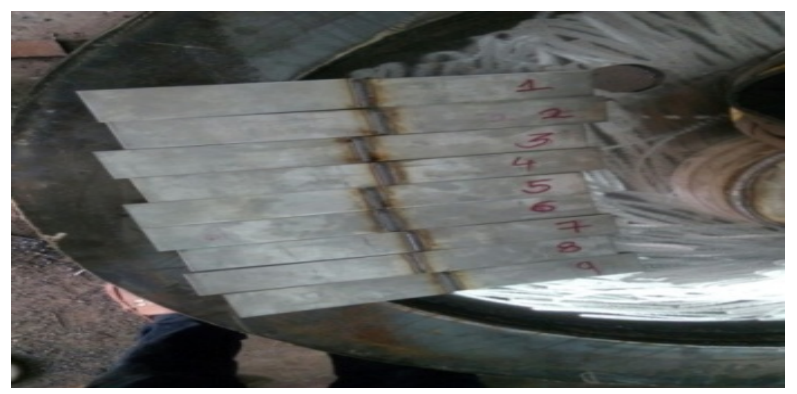

Figure 3: TIG Welded Joint.
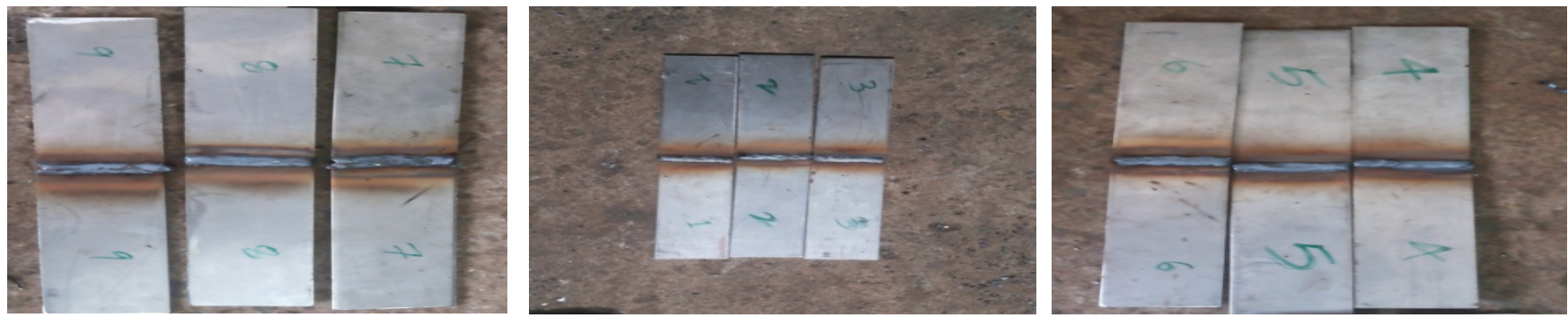

Figure 4: MIG Welded Join.

\subsection{Tabulations and Graphs}

Welding speed $=$ Welding Distance $/$ Welding time $(\mathrm{m} / \mathrm{sec})$.

$\mathrm{H}=\mathrm{V} * \mathrm{I} * 60 / \mathrm{S}(\mathrm{kW})$

$\mathrm{H}=$ Heat Input, V=Voltage, I=Welding Current, $\mathrm{S}=$ Welding speed

Table $2 \& 3$ represent the input parameters for TIG \& MIG Welding, from Figure 5 to 12 shown plots of various parameters.

Table 2: Input Parameters of TIG Welding

\begin{tabular}{|c|c|c|c|c|c|c|}
\hline $\begin{array}{c}\text { S. } \\
\text { N } \\
\mathbf{o}\end{array}$ & $\begin{array}{c}\text { Voltage } \\
\text { (Volts) }\end{array}$ & $\begin{array}{c}\text { Current } \\
\text { (Amps) }\end{array}$ & $\begin{array}{c}\text { Welding Speed } \\
\text { (Mm / Sec) }\end{array}$ & $\begin{array}{c}\text { Type of Weld } \\
\text { Joint }\end{array}$ & $\begin{array}{c}\text { Heat Input } \\
\text { (kw) }\end{array}$ & $\begin{array}{c}\text { Time Required for } \\
\text { Welding (Sec) }\end{array}$ \\
\hline 1 & 70 & 350 & 2.5 & S-S & 588000 & 40 \\
\hline 2 & 71 & 352 & 2.1 & V-V & 714057 & 46 \\
\hline 3 & 72 & 355 & 2.1 & S-V & 730285 & 47 \\
\hline 4 & 80 & 399 & 2.7 & V-V & 709333 & 36 \\
\hline 5 & 82 & 400 & 2.6 & S-V & 756923 & 38 \\
\hline 6 & 83 & 402 & 2.9 & S-S & 690331 & 34 \\
\hline 7 & 91 & 449 & 3.1 & S-V & 790819 & 32 \\
\hline
\end{tabular}




\begin{tabular}{|l|l|l|l|l|l|l|}
\hline 8 & 92 & 452 & 3.3 & S-S & 756072 & 30 \\
\hline 9 & 92 & 453 & 2.9 & V-V & 862262 & 34 \\
\hline
\end{tabular}

\subsection{TIG Welding Graphs}

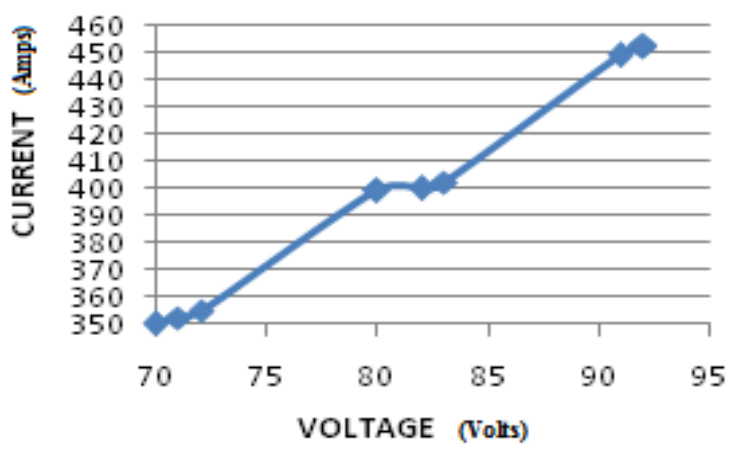

Figure.5. Voltage vs. Current.

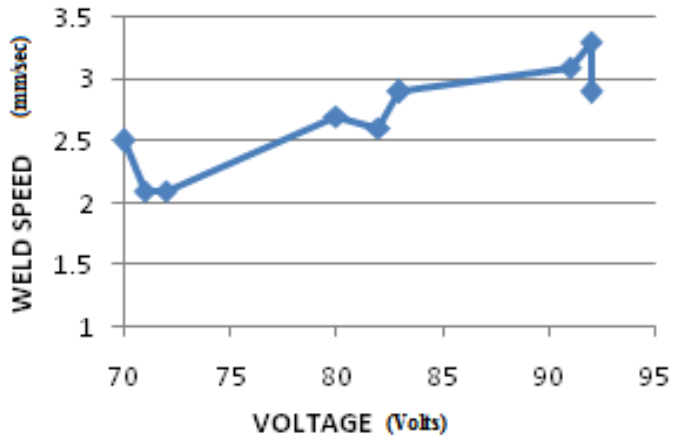

Figure 6: Voltage Vs. Weld Speed.

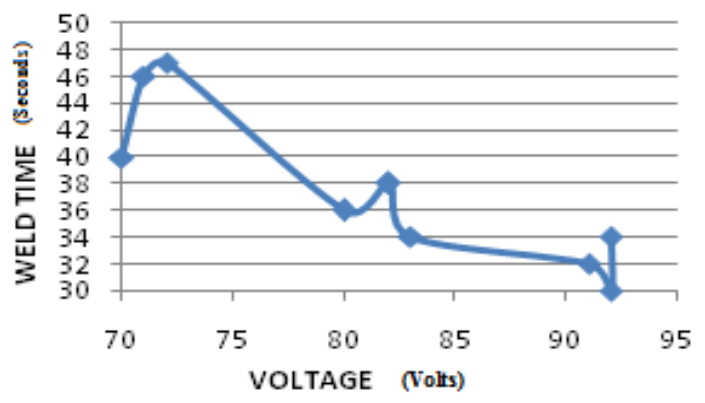

Figure.7. Voltage Vs Weld Time.

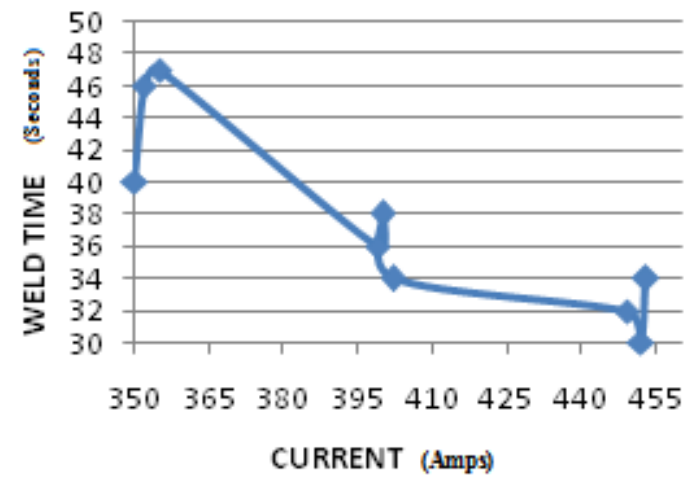

Figure 8: Current Vs Welding Time. 


\subsection{MIG Welding Graphs}

Table: 3.Input Parameters of MIG Welding

\begin{tabular}{|c|c|c|c|c|c|c|}
\hline S. No & $\begin{array}{c}\text { Voltage } \\
\text { (Volts) }\end{array}$ & Current(Amps) & $\begin{array}{c}\text { Welding Speed } \\
\text { (M / Sec) }\end{array}$ & $\begin{array}{c}\text { Type of } \\
\text { Weld Joint }\end{array}$ & $\begin{array}{c}\text { Heat Input } \\
\text { (Kj / Mm) }\end{array}$ & $\begin{array}{c}\text { Time Required } \\
\text { for Welding (Sec) }\end{array}$ \\
\hline 1 & 71 & 349 & 6.2 & S-S & 239796 & 16 \\
\hline 2 & 72 & 352 & 6.8 & V-V & 223623 & 14.6 \\
\hline 3 & 73 & 354 & 6.4 & S-V & 242268 & 15.5 \\
\hline 4 & 80 & 398 & 6.3 & V-V & 303238 & 15.7 \\
\hline 5 & 81 & 400 & 7.1 & S-V & 273802 & 14 \\
\hline 6 & 82 & 401 & 6.6 & S-S & 298927 & 15 \\
\hline 7 & 90 & 449 & 6.6 & S-V & 367363 & 15 \\
\hline 8 & 91 & 451 & 7.6 & S-S & 324007 & 13 \\
\hline 9 & 93 & 454 & 7.2 & V-V & 351850 & 13.7 \\
\hline
\end{tabular}

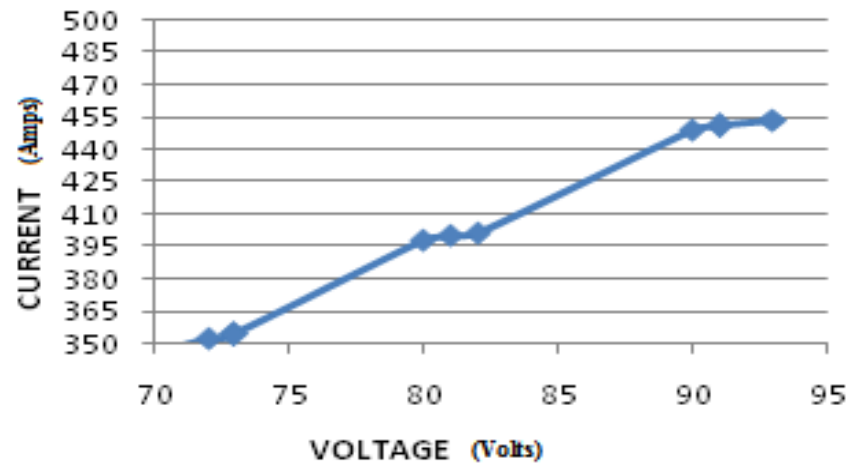

Figure 9: Voltage Vs Current.

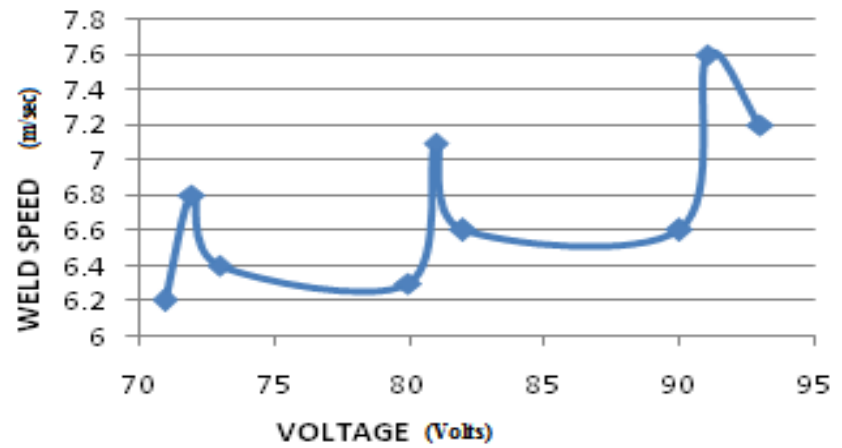

Figure 10: Voltage Vs Welding Speed.

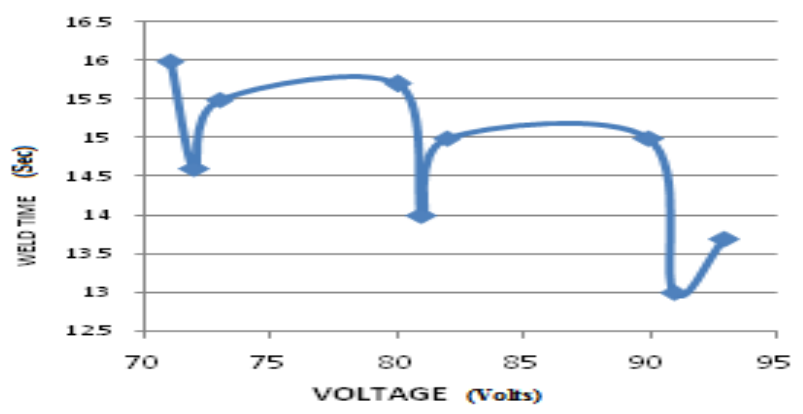

Figure 11: Voltage Vs Weld Time. 


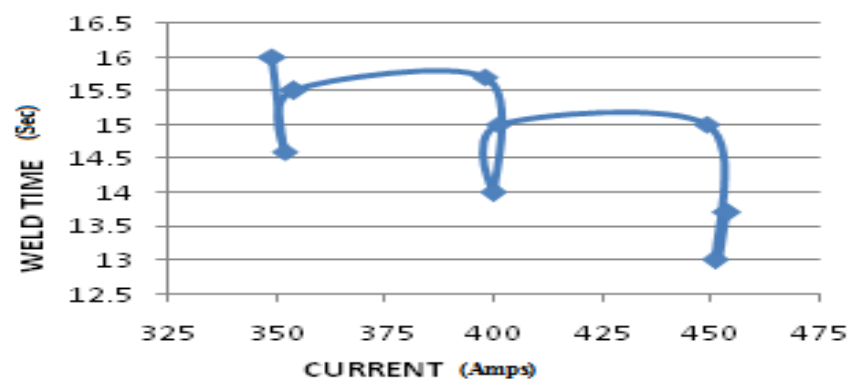

Figure 12: Current Vs Welding Time.

\section{RESULTS AND DISCUSSIONS}

Welding width for all the samples were measured and calculated average welding width as shown in table 4 \& 5 below. Average value of welding width then plotted against the applied welding voltage for different welding speed as shown in Figure $13 \& 14$. From the plot it is clearly seen that welding width increases almost linearly with increase of welding current.

Table 4: Weld Width of TIG Welding Joint

\begin{tabular}{|c|c|c|c|c|}
\hline Sample No & Reading 1 $\mathbf{( M m})$ & Reading 2 $\mathbf{( M m})$ & Reading 3 $\mathbf{( M m})$ & Avg. Width (Mm) \\
\hline 1 & 4.0 & 3.8 & 3.5 & 3.76 \\
\hline 2 & 4.2 & 3.8 & 3.5 & 3.83 \\
\hline 3 & 4.3 & 4.0 & 3.8 & 4.03 \\
\hline 4 & 4.6 & 4.4 & 4.1 & 4.36 \\
\hline 5 & 4.6 & 4.4 & 4.1 & 4.36 \\
\hline 6 & 4.6 & 4.4 & 4.2 & 4.4 \\
\hline 7 & 4.9 & 4.6 & 4.2 & 4.56 \\
\hline 8 & 4.8 & 4.5 & 4.4 & 4.56 \\
\hline 9 & 5.0 & 4.8 & 4.1 & 4.63 \\
\hline
\end{tabular}

Table 5: Weld Width of MIG Welding Joint

\begin{tabular}{|c|c|c|c|c|}
\hline Sample No & Reading 1 $(\mathbf{M m})$ & Reading 2 $\mathbf{( M m})$ & Reading 3 $(\mathbf{M m})$ & Avg. Width (Mm) \\
\hline 1 & 7.5 & 7.3 & 7.1 & 7.30 \\
\hline 2 & 7.9 & 7.5 & 7.3 & 7.56 \\
\hline 3 & 7.9 & 7.6 & 7.4 & 7.63 \\
\hline 4 & 8.1 & 7.8 & 7.6 & 7.83 \\
\hline 5 & 8.7 & 8.6 & 8.2 & 8.50 \\
\hline 6 & 8.8 & 8.5 & 8.4 & 8.56 \\
\hline 7 & 8.9 & 8.6 & 8.5 & 8.66 \\
\hline 8 & 9.1 & 8.8 & 8.6 & 8.83 \\
\hline 9 & 9.8 & 9.5 & 9.3 & 9.53 \\
\hline
\end{tabular}

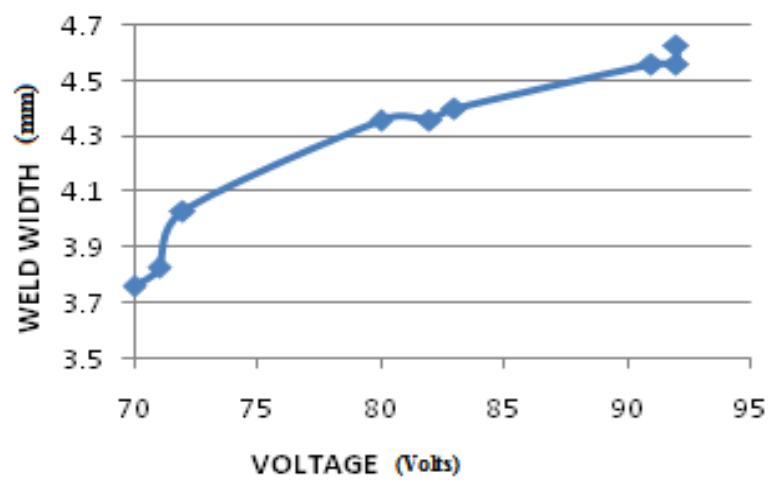

Figure 13: Voltage Vs Weld Width of TIG Welding. 


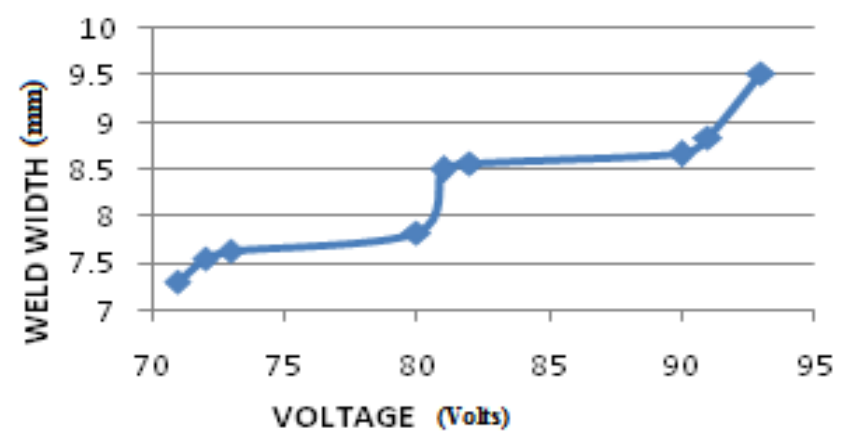

Figure 14: Voltage Vs Weld Width of MIG Welding.

\subsection{Non-Destructive Testing on Welded Joints}

It is fact that there are inherent flaws in materials due to crystal lattice imperfections and dislocations however microscopic they may be. Manufacturing processes such as welding, casting, forging, surface treatment, etc. may cause further flaws or defects. While there are many different methods of NDT only the more common NDT methods used for the evaluation of materials and welds will be outlined here. These methods are the following:

\subsection{Liquid Penetration Inspection}

Liquid penetrate inspection (LPI) is one of the most widely used Non Destructive Evaluation (NDE) methods. Its popularity can be attributed to two main factors, which are its relative ease of use and its flexibility. The technique is based on the ability of a liquid to be drawn into a "clean" surface breaking flaw by capillary action. Liquid penetration Test carried for the above mentioned plates (TIG, MIG) at weld area and no relevant indication was found at time of inspection. Hence acceptable as per applicable acceptance criteria.

\subsection{Magnetic Particle Testing}

Magnetic particle inspection is one of the simple, fast and traditional nondestructive testing methods widely used because of its convenience and low cost. This method uses magnetic fields and small magnetic particles, such as iron filings to detect flaws in components. Magnetic particle Testing carried out for weld joints, defect indication observed on the MIG weld Plates at the time of inspection hence not acceptable as per standard. No indication found on TIG weld Plates at the time of inspection therefore accepted as per standard.

\subsection{Radiographic Inspection}

Radiography has an advantage over some of the other processes in that the radiography provides a permanent reference for the internal soundness of the object that is radio graphed. The x-ray emitted from a source has an ability to penetrate metals as a function of the accelerating voltage in the x-ray emitting tube. Radiographic inspection on welded joint, Lack of Fusion defect observed on the MIG weld plates at the time of inspection, hence not acceptable as per standard.No indications on TIG weld plate at the time of inspection, therefore accepted as per standard.

\subsection{Mechanical Testing on Welded Joints}

\subsubsection{Tensile Testing}

A servo-hydraulic or servo-mechanical testing machine is used. The specimen of known dimensions are loaded in the machine and strained at a constant rate. The load is measured by a load cell. The crosshead movement and/or strain are recorded. Table $6 \& 7$ represents weld strength values for TIG \& MIG welding. Figure $15 \& 16$ shows stress plots. 


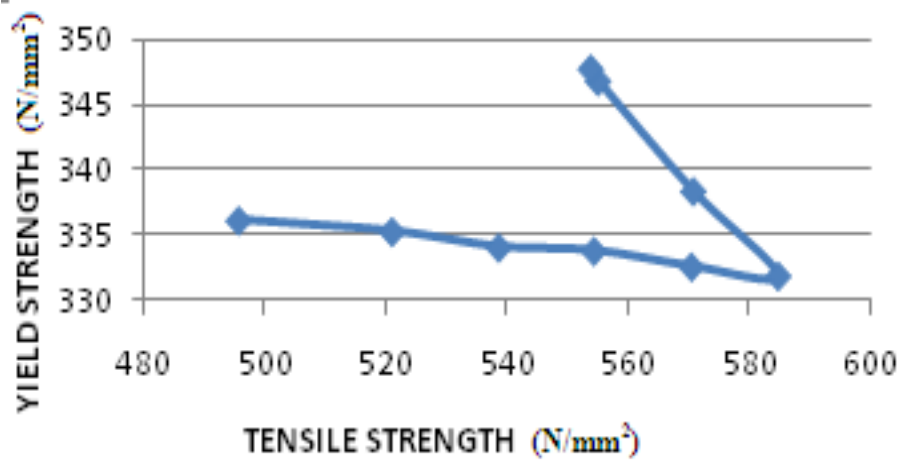

Figure 15: Tensile Vs Yield Strength on TIG Welding Joint.

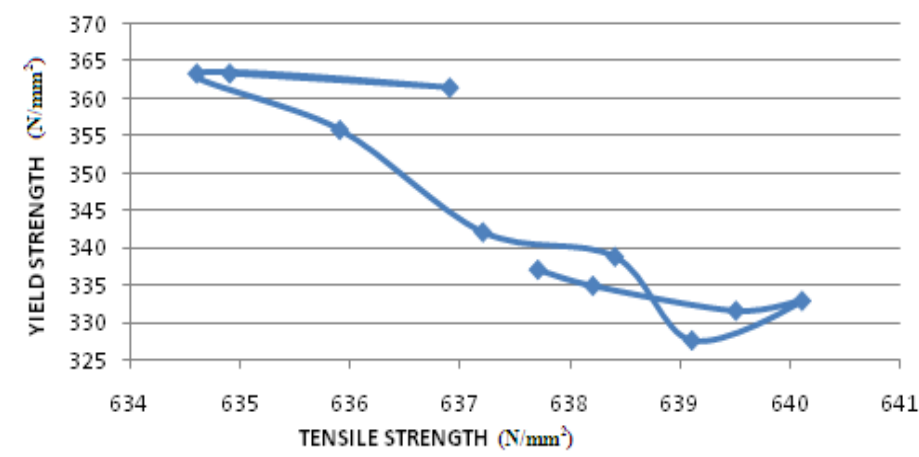

Figure 16: Tensile Vs Yield Strength on MIG Welding Joint.

Table: 6.Tensile Testing on TIG Welding Joint.

\begin{tabular}{|c|c|c|}
\hline S. No & Tensile Strength (N / Mm²) & Yield Strength $\left(\mathrm{N} / \mathrm{Mm}^{2}\right)$ \\
\hline 1 & 495.6 & 336.16 \\
\hline 2 & 520.9 & 335.30 \\
\hline 3 & 538.5 & 334.10 \\
\hline 4 & 554.2 & 333.82 \\
\hline 5 & 570.3 & 332.62 \\
\hline 6 & 584.6 & 331.9 \\
\hline 7 & 570.6 & 338.41 \\
\hline 8 & 554.9 & 346.86 \\
\hline 9 & 553.7 & 347.8 \\
\hline
\end{tabular}

Table 7: Tensile Testing on MIG Welding Joint

\begin{tabular}{|c|c|c|}
\hline S. No & Tensile Strength $\left(\mathbf{N} / \mathbf{M m}^{2}\right)$ & Yield Strength $\left(\mathbf{N} / \mathbf{M m}^{\mathbf{2}}\right)$ \\
\hline 1 & 634.6 & 363.46 \\
\hline 2 & 635.9 & 355.9 \\
\hline 3 & 637.2 & 342.2 \\
\hline 4 & 638.4 & 338.9 \\
\hline 5 & 639.1 & 327.7 \\
\hline 6 & 640.1 & 332.99 \\
\hline 7 & 639.5 & 331.67 \\
\hline 8 & 638.2 & 335.01 \\
\hline 9 & 637.7 & 337.16 \\
\hline
\end{tabular}

\subsection{Hardness Testing}

Hardness is generally considered as resistance to penetration. Perform Brinell hardness measurements on designated specimens (3 Readings). Table 8 \& 9 represents Hardness values for TIG \& MIG welding. Figure 17 \& 18 shows hardness vs. stress plot. 
Table 8: Hardness Value of TIG Welded Joint

\begin{tabular}{|c|c|c|}
\hline S. No & Hardness Value (BHN) & Tensile Strength $\left(\mathbf{N} / \mathbf{M m}^{\mathbf{2}}\right)$ \\
\hline 1 & 183.7 & 495.6 \\
\hline 2 & 183.9 & 520.9 \\
\hline 3 & 184.1 & 538.5 \\
\hline 4 & 184.5 & 544.2 \\
\hline 5 & 184.7 & 550.3 \\
\hline 6 & 184.3 & 554.9 \\
\hline 7 & 185.2 & 570.6 \\
\hline 8 & 185.3 & 584.6 \\
\hline 9 & 185.5 & 587.7 \\
\hline
\end{tabular}

Table 9: Hardness Value of MIG Welded Joints

\begin{tabular}{|c|c|c|}
\hline S. No & Hardness Value (BHN) & Tensile Strength $\left(\mathrm{N} / \mathrm{Mm}^{2}\right)$ \\
\hline 1 & 410.1 & 634.6 \\
\hline 2 & 410.3 & 635.9 \\
\hline 3 & 410.9 & 636.2 \\
\hline 4 & 411.5 & 637.4 \\
\hline 5 & 411.9 & 638.8 \\
\hline 6 & 411.2 & 638.2 \\
\hline 7 & 413.5 & 639.5 \\
\hline 8 & 414.4 & 640.1 \\
\hline 9 & 414.8 & 641.7 \\
\hline
\end{tabular}

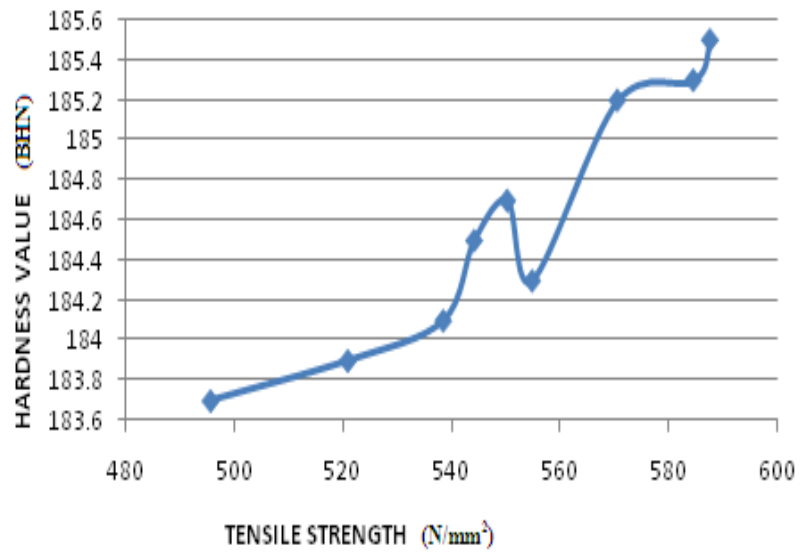

Figure 17: Tensile Strength Vs Hardness Value.

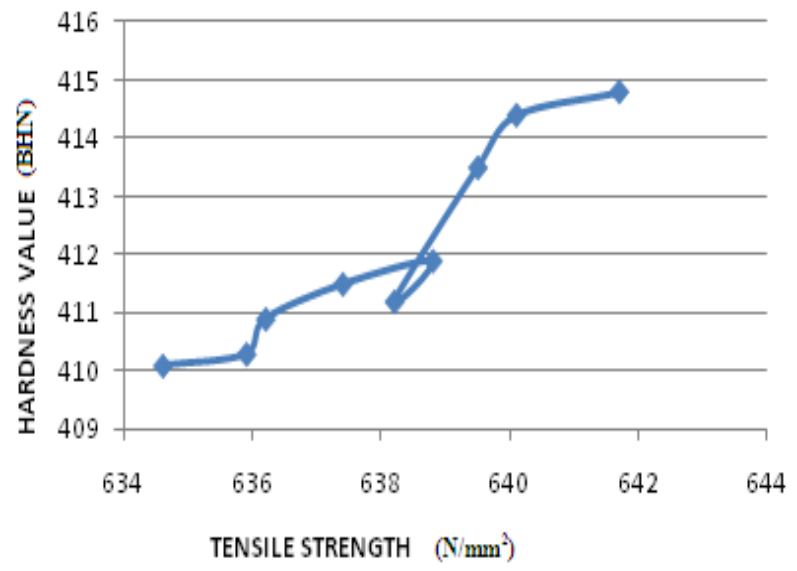

Figure 18: Tensile Strength Vs Hardness Value. 


\subsection{Microscopically Examination}

The micro structural study of a material can provide information regarding the morphology and distribution of constituent phases as well as the nature and pattern of certain crystal imperfections

\section{Micro Structural Examination Can Provide Quantitative Information About The Following Parameters:}

- The grain size of specimens

- The amount of interfacial area per unit volume

- The dimensions of constituent phases

- The amount and distribution of phases.

Magnifications up to $1000 \mathrm{x}$ can be obtained with a resolution of $2 \mathrm{Vm}$. For grain size measurements, the grains along a line, circle, or within a known area are counted. It would be useful to obtain an average value of grain diameter from a micro structural section. In linear intercept method, the grains intercepted by a theoretical line on the specimen surface are counted (Figure. 19, 20). The number of grain boundaries intersected per unit length of a test line (N1) can be noted. The average grain size is indicated by the inverse of NL, corrected for the magnification, M, of the micrograph. In general, then, the average grain diameter, $\mathrm{d}$, is given by

$$
\mathrm{d}=\mathrm{C} / \mathrm{N} 1 . \mathrm{M}
$$

Where $\mathrm{C}$ is some constant greater than 1 (Typically, a value of $\mathrm{C}=1.5$ is Adequate).

\section{RESULTS}

\subsection{Microstructure of TIG Welded Joint}

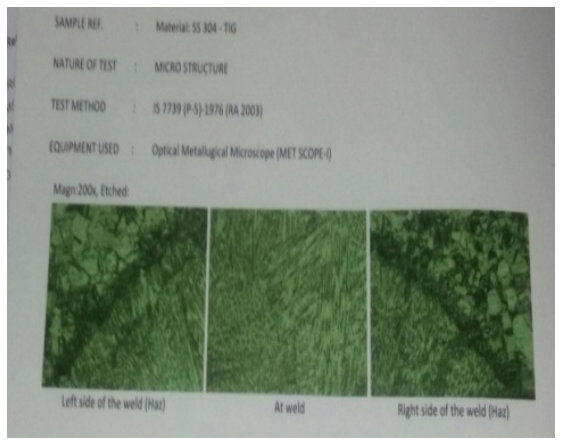

4.2. Microstructure of MIG Welded Joint
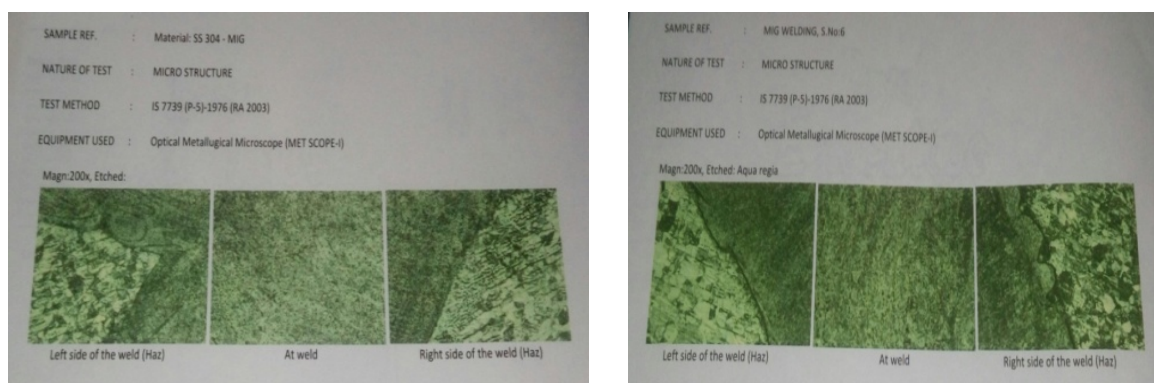

Figure 20

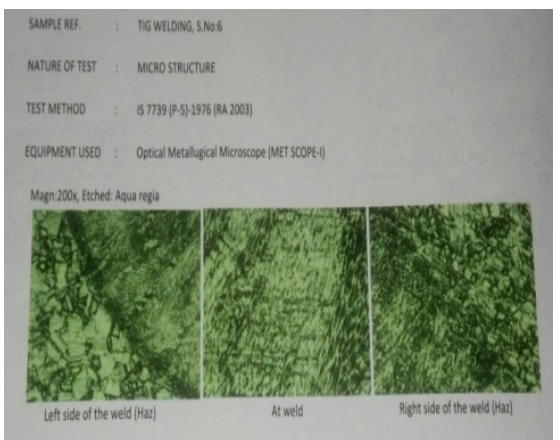

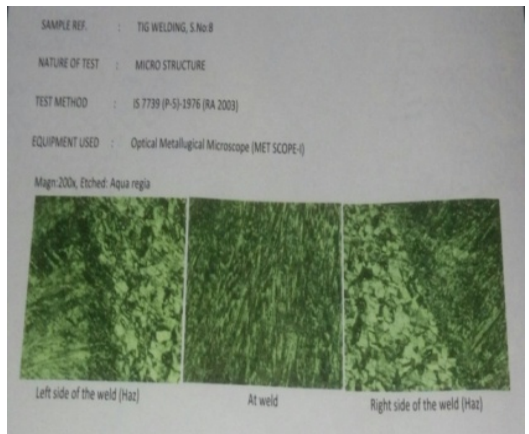

Figure 19 


\section{CONCLUSIONS}

During the study of stainless steel were joined using TIG and MIG welding process. The Non Destructive Testing is investigated on welded joints of TIG and MIG Welding. Following conclusions were drawn-

- $\quad$ The Liquid penetrate inspection is best for both TIG and MIG welding.

- The Magnetic particle testing on TIG welding joint has better result compared to MIG welding joint.

- The Radiographic inspection has poor result for MIG welding as compared to TIG welding due to Lack of Fusion.

- Mechanical tests like Tensile Testing, Hardness Testing and Microstructure of welded joints were also studied. The selection of different grades of stainless steel used for welding play an important role in deciding the properties of the weld. From the study, following conclusions were drawn -

- Tungsten Inert Gas Welding is more suitable than Metal Inert Gas welding for welding of stainless steel; TIG welding process provides better strength.

- It may be because of less porosity in metal welds during TIG welding and carbon precipitation which comes out due to welding is also less

- The main flaw which occurs in welding Stainless steel material by MIG is the development of cracks during the welding, which needs more effort for achieving similar weld has by TIG welding.

- The yield strength of MIG Welded Process is superior to TIG Welded process.

- The ultimate tensile stress of MIG welding process is higher than TIG Welding process.

- The Hardness Value of MIG Welding joint is higher when compared with the Hardness Value of TIG welding joints.

- Hence Experimental result concludes that for all Mechanical Properties MIG is superior to TIG.

\section{REFERENCES}

1. Zhou, J., \& Tsai, H. L. (2008). Modeling of transport phenomena in hybrid laser-MIG keyhole welding. International Journal of Heat and Mass Transfer, 51(17-18), 4353-4.

2. Ahmad, Asif, and ShahnawajAlam. "Parametric optimization of tig welding to determine welding strength of S30430 stainless steel." International Journal of Mechanical and Production Engineering Research and Development (IJMPERD) ISSN (P), 22496890

3. Bagger, C., \& Olsen, F. O. (2005). Review of laser hybrid welding. Journal of laser applications, 17(1), 214.

4. Kim, T., Suga, Y., \& Koike, T. (2003). Welding of thin steel plates by hybrid welding process combined TIG arc with YAG laser.JSME International Journal Series A Solid Mechanics and Material Engineering, 46(3), 202207.

5. Devireddy, K. R. I. S. H. N. A. J. A., et al. "Analysis of the influence of friction stir processing on gas tungsten arc welding of 2024 aluminum alloy weld zone." Int. J. Mech. Prod. Eng. Res. Dev 8.1 (2018): 243252.

6. Chen, J., Wu, C. S., \& Chen, M. A. (2014). Improvement of welding heat source models for TIG-MIG hybrid welding process. Journal of Manufacturing Processes, 16(4), 485493. 
7. SALUJA, RATI, and K. M. Moeed. "Depiction of detrimental metallurgical effects in grade 304 austenitic stainless steel arc welds." International Journal of Mechanical and Production 8.6 (2018): 207218.

8. Patnaik, A., Biswas, S., \&Mahapatra, S. S. (2007). An evolutionary approach to parameter optimisation of submerged arc welding in the hardfacing process.

9. Duhan, R. A. V. I., and S. U. R. A. J. Choudhary. "Effect of different fluxes on hardness and microstructure of SS 304 in GTAW welding." International Journal of Mechanical Engineering 3.4 (2014): 1-8.

10. Ghazvinloo, H. R., Honarbakhsh-Raouf, A., \&Shadfar, N. (2010). Effect of arc voltage, welding current and welding speed on fatigue life, impact energy and bead penetration of AA 6061 joints produced by robotic MIG welding. Indian Journal of Science andTechnology, 3(2).

11. R S Parmar, Welding engineering \& technology, Khanna Publisher, 2002, 2nd edition, New Delhi.

12. S V Nadkarni, Modern Arc Welding Technology, Ador Welding Limited, 2010, New Delhi. 